BULLETIN Bulletin hispanique

HISPANIQUE Université Michel de Montaigne Bordeaux

116-1 | 2014

Varia

\title{
Territorios cicatriciales en la narrativa de Juan
}

Marsé

el caso de Rabos de lagartija

Ioana Gruia

\section{OpenEdition}

Journals

Edición electrónica

URL: http://journals.openedition.org/bulletinhispanique/2975

DOI: 10.4000/bulletinhispanique.2975

ISSN: $1775-3821$

Editor

Presses universitaires de Bordeaux

Edición impresa

Fecha de publicación: 1 junio 2014

Paginación: 263-281

ISBN: 978-2-86781-931-5

ISSN: 0007-4640

Referencia electrónica

Ioana Gruia, «Territorios cicatriciales en la narrativa de Juan Marsé », Bulletin hispanique [En línea],

116-1 | 2014, Publicado el 01 junio 2017, consultado el 23 mayo 2020. URL : http://

journals.openedition.org/bulletinhispanique/2975; DOI : https://doi.org/10.4000/bulletinhispanique. 2975

Tous droits réservés 


\title{
Territorios cicatriciales en la narrativa de Juan Marsé: el caso de Rabos de lagartija
}

\author{
IOANA GRUIA \\ Universidad de Granada
}

Cet article se propose d'établir et d'analyser la cicatrice en tant que noyau de signification fondamental dans l'auvre de Juan Marsé, notamment dans Des lézards dans le ravin. Les éléments qui présentent des cicatrices -le corps, l'intimité, l'histoire et la ville-seront dénommés territoires cicatriciels et examinés en tant que tels.

Mots-clés : cicatrice, territoires cicatriciels, Juan Marsé, Des lézards dans le ravin.

Mi artículo se propone enunciar y analizar la cicatriz como núcleo de significación fundamental en la narrativa de Juan Marsé, sobre todo en Rabos de lagartija. Los elementos que presentan cicatrices - el cuerpo, la intimidad, la historia y la ciudad-serán formulados y examinados en tanto que territorios cicatriciales.

Palabras claves: cicatriz, territorios cicatriciales, Juan Marsé, Rabos de lagartija.

My article aims at establishing and analysing the scar as a fundamental core of signification in Juan Marsé's literary work, especially in "Lizard Tails". I will state and examine the elements that present scars - the body, the intimacy, the history and the cityas scar territories.

Keywords: scar, scar territories, Juan Marsé, Lizard Tails.

$\mathrm{U}^{\mathrm{s}}$ na lectura atenta de la obra del novelista español Juan Marsé permite observar la presencia recurrente, obsesiva podríamos decir, de un elemento que se convierte en un núcleo de significación, en un generador y 
aglutinador de numerosos focos: la cicatriz. Estos focos, que representan a su vez otras constelaciones fundamentales de la narrativa del escritor barcelonés, son el cuerpo, la historia (especialmente de la Guerra Civil española y de la posguerra) y la ciudad. Recordemos en este sentido las cicatrices que surcan la piel de Aurora Nin/ Ramona en Si te dicen que caí o la cicatriz en el muslo de Milena en Canciones de amor en Lolita's club. La cicatriz, que atraviesa toda la obra de Marsé ${ }^{1}$, es una huella indeleble tanto en el cuerpo como en la historia personal y, por supuesto, en la historia colectiva. También constituye un rasgo definitorio de ciertas partes de la ciudad de Barcelona, de los barrios de Carmelo o Guinardó, o, como se estudiará en el presente análisis, del barranco de Rabos de lagartija. En este sentido se puede afirmar que no sólo los cuerpos de los personajes, sino también la intimidad, la historia y la propia geografía urbana y sentimental se encuentran en Marsé marcadas por las cicatrices hasta el punto de convertirse en lo que he llamado, inspirándome en una expresión de la escritora francesa Hélène Cixous ${ }^{2}$, territorios cicatriciales. Para Cixous, la cicatriz es un foco importantísimo a múltiples niveles, un núcleo estrechamente ligado al cuerpo (por ejemplo el cuerpo mutilado de la Medusa en el famoso ensayo Le Rire de la Méduse o el cuerpo llagado de la madre en Hyperrêve), a la historia íntima y colectiva, a las ruinas, todos ellos ejemplos de los «domaines cicatriciels» a los que se refiere la autora, ámbitos que comparten la cicatriz como huella de la herida, de la pérdida, del trauma ${ }^{3}$.

Este trabajo se propone formular y analizar el cuerpo, la historia y el espacio como territorios cicatriciales en la novela Rabos de lagartija (2000). En este sentido son muy importantes las reflexiones que Catherine Malabou plantea en el capítulo «Le phénix, l'araignée et la salamandre» de su libro Changer de

1. Incluso cuando no remite estrictamente a lo que he llamado «territorios cicatriciales»; recordemos por ejemplo la pequeña cicatriz en la cara interna del muslo de Norma Valentí en $E l$ amante bilingüe (cfr. Barcelona, Planeta, 2001, p. 32-33).

2. La expresión es «domaines cicatriciels» que Cixous formula en Manhattan. Lettres de la préhistoire (Paris, Galilée, 2002, p.189). En este libro la escritora desarrolla toda una reflexión en torno a la cicatriz y sobre todo al íntimo vínculo entre cicatriz y literatura: "D'ailleurs la Littérature tout entière est cicatricielle. Elle célèbre la plaie et redit la lésion» (ibidem).

3. Para una mejor comprensión cabe citar en este sentido el siguiente párrafo de Manhattan. Lettres de la préhistoire: «La Cicatrice: The Scar. Thème d'une richesse signifiante extraordinaire, à tous les niveaux et sous tous les aspects, tant langagier, effets de langue dans l'idiome américain (Scar, Star) tant littéral que métaphorique que psychanalytique : trauma, trace d'une blessure, tissu fibreux visible ou invisible qui remplace réellement ou allégoriquement une perte de substance qui donc n'est pas perdue mais suppléée, bourrelet mnésique; tant au niveau philosophique trace, greffe, graphe, marque; qu'au nivean géologique, géographique, géopolitique: il faudrait citer aussi bien le sillon que la frontière, tous les tracés matériels, symboliques, immatériels, évoquer le vestige et la ruine, tous les discours sur les ruines dans la culture occidentale, tous les Romantismes tournant autour des ruines, parfois perçues comme élévations, amas de tessons ou au contraire comme trous, lacunes, monuments à l'absence, ou au contraire à la persistance, selon le point de vue et l'affect (du lecteur) de l'interprète, rapport entre la ruine naturelle (cratère de volcan, ligne de chasme) et la ruine culturelle; présence du passé, splendeur du passé, hideur du passé, splendide hideur du passé, passé du passé, bénéfices $d u$ deuil, manque d'une dent dans la mâchoire supérieure superficielle métaphore de la mortalité, etc. Innombrables sont les domaines cicatriciels.» (ibidem) 
différence. Le féminin et la question philosophique ${ }^{4}$. Malabou, que ya estableció un vínculo entre Hegel y el concepto de "plasticidad" ${ }^{5}$, formula aquí tres paradigmas de interpretación de la famosa frase de Fenomenología del espiritu, "las heridas del espíritu se curan sin dejar cicatriz» ${ }^{6}$. Estos tres paradigmas son el del fénix, el de la araña ${ }^{7}$ y el de la salamandra. En el caso de la salamandra, si se le corta el rabo éste se reconstituye sin que la cicatriz sea visible, lo que no significa que el nuevo órgano no sea diferente del anterior: "Il n'y a pas cicatrice mais il y a différence» ${ }^{8}$. Malabou encuentra una correspondencia entre esta borradura de cualquier huella del corte y de la cicatriz y la borradura de la escritura: "La salamandre ne se laisse pas entièrement prendre dans les plis du texte. Elle guérit en effaçant l'écriture. La salamandre nous rappelle en effet que la régénération est une déprogrammation, une "désécriture" si l'on veut»".

Extrapolando las reflexiones de Malabou, si la cicatriz es el testimonio visible de la herida y de la presencia de un pasado traumático, la ausencia de cicatriz en la salamandra no anula la mutilación, sino que la esconde bajo la apariencia de una total regeneración. Aunque el corte y la cicatriz no son visibles, ellos existen, cubiertos, ocultos, borrados. Así, en el caso de Rabos de lagartija la historia de los vencidos de la Guerra Civil es cubierta, oculta, borrada, "desescrita” digamos, por la historia oficial y forzada a transformar en cicatrices -y a hacerlas también desaparecer- heridas que no acaban de cicatrizar. La cicatriz se transforma por consiguiente en una narración que debe recurrir a complejos, ramificados y distorsionados mecanismos de ficcionalización para hacerse visible. "J'aime la cicatrice, ce récit» ${ }^{10}$, afirma Hélène Cixous, estableciendo de este modo el vínculo entre cicatriz y narración, ya que detrás de cada cicatriz hay una historia.

En Rabos de lagartija los adolescentes David Bartra y Paulino Bradolet, habitantes de la Barcelona de posguerra, están siempre cortando rabos de lagartija. Estos cortes que marcan el ritmo de la novela se encuentran en relación con otros cortes de varias narraciones entremezcladas: la narración de la desaparición del padre ${ }^{11}$ de David, perseguido por la policía franquista, la narración del aviador británico y de su historia de amor con la madre de David,

4. Paris, Galilée, 2009, p. 81-104. Se cita siempre de esta edición.

5. L'Avenir de Hegel. Plasticité, temporalité, dialectique, Paris, Vrin, 1996.

6. Hegel Georg Wilhelm Friedrich, Fenomenología del espiritu, trad. de Wenceslao Roces, México, Fondo de Cultura Económica, 1966, p. 390.

7. Otro elemento fundamental en la obra de Juan Marsé; puede consultarse al respecto el artículo de Silvina Bénévent González, «Si te dicen que caí de Juan Marsé: images du mythe de l'Arachné", Amaltea. Revista de mitocritica, 2, 2010, 9-22.

8. Changer de différence..., p. 97.

9. Op. cit., p. 101.

10. Calle-Gruber Mireille, Cixous Hélène, Hélène Cixous, photos de racines, Paris, Des femmes, 1994, p. 26.

11. Manuel Vázquez Montalbán, en «La memoria de Juan Marsé», Nuevas tardes con Marsé: Ensayos sobre la obra de Juan Marsé, eds. José Belmonte Serrano y José Manuel López Abada, Murcia, Nausicaa, 2002, p. 274, vincula la ausencia del padre, dominante en la obra de Marsé, a la cicatriz, subrayando el «mito del padre aplazado» que «subyace en sus novelas como sombra o cicatriz, adivinadas». 
la narración del inspector Galván sobre el expediente del padre de David y las narraciones que David se inventa continuamente sobre su padre, su madre, su hermano muerto, el inspector y el aviador. Entre todas estas narraciones se tejen las narraciones de la historia colectiva, la narración oficial de los vencedores y la narración ocultada, borrada, no cicatrizada, de los vencidos. Teniendo en cuenta la recurrencia de la cicatriz en Marsé, podemos hablar de la historia como cicatriz en el cuerpo. La intimidad y la historia se convierten así en narraciones de cicatrices. Si la versión oficial es un intento de hacer invisible la historia, de borrar sus cicatrices -intento que implica evidentemente sus mecanismos de ficcionalización-, las narraciones que David se inventa tratando de unir los trozos de verdad a los que tiene acceso desvelan la existencia de muchas cicatrices tanto a nivel de la historia familiar como a nivel de la historia colectiva.

Para demostrar la hipótesis de partida del artículo, el hecho de que el cuerpo, la historia y la ciudad son en Marsé territorios cicatriciales, estudiaré estas articulaciones, fuertemente relacionadas entre sí, en el caso de Rabos de lagartija. Las cicatrices del cuerpo son las cicatrices de la intimidad y de la historia y también las de una geografía urbana y sentimental resquebrajada, marcada tanto por los bombardeos y la miseria como, metafóricamente, por la distorsión de la historia.

La cicatriz en el cuerpo aparece varias veces en Rabos de lagartija. El «rabo cercenado de una lagartija ${ }^{12}$ anticipa de alguna manera todas la cicatrices de los personajes. Así, encontramos la "cicatriz como un relámpago» que David imagina en la cara de su padre, Víctor Bartra, y que en realidad, como le explica su madre, está en su nalga. Se opera de este modo una desmitificación lúcida y sutil de la narración heroica que David podría sentir la tentación de inventarse: según la madre, la cicatriz no está en la cara (como la cicatriz que surca el rostro de Kutuzov en Guerra y paz, obra con la que dialoga continuamente Rabos de lagartija); no representa pues un testimonio venerable $\mathrm{y}$, en consecuencia, susceptible de idealización, sino en la nalga, en un lugar que no se puede enseñar y que subvierte cualquier mitificación ${ }^{13}$ : «Tu padre se dejó ir por la ladera resbalando de culo. La mala suerte quiso que pillara un cristal afilado, seguramente la esquirla de una botella rota, y le rajó la nalga como si fuera una sandía. Esto fue lo que ocurrió. Ni más ni menos» ${ }^{14}$. Pero ni siquiera se puede hablar de una verdadera cicatriz, es decir de una herida cerrada, porque el padre, en las historias que se inventa David y en sus sueńos, se presenta siempre sangrando sin parar: "con una mano ensangrentada en el culo y

12. Juan Marsé, Rabos de lagartija, Barcelona, Debolsillo, 2000, p. 12. Se cita siempre de esta edición.

13. Marsé afirma al respecto, en Gracia Jordi y Maurel Marcos, «Conversación con Juan Marsé», Cuadernos Hispanoamericanos, 628, 2002, p. 51: «La figura del padre, del luchador por las libertades, se ha convertido en una especie de guiñapo sanguinolento. Esa mitificación que había antes (en Un día volveré y en otras novelas) acerca de esto, en Rabos no hay».

14. Rabos de lagartija, p. 16. 
balanceando la botella en la otra» ${ }^{15}$, «dejando en el pedregal del torrente un reguero de sangre» ${ }^{16}$, «en una mano la botella y la cerilla, y en otra el pańuelo ensangrentado que aprieta contra la nalga ${ }^{17}$. La sangre imposible de detener es de hecho un núcleo de significación básico de la novela y una "marca" podríamos decir de la familia Bartra. Así lo atestigua David al exclamar en el encuentro imaginado con su hermano Juan, muerto en un bombardeo años atrás: «en esta familia todos sangramos como cerdos»" ${ }^{18} \mathrm{La}$ sangre imparable se encuentra en íntima relación con las "heridas mal cerradas» que atraviesan Rabos de lagartija, aunque sólo se mencionen de manera explícita dos veces, las dos en relación al barranco y a su carácter de depositario de una memoria histórica y sentimental que es «la memoria desvanecida de la sangre» ${ }^{19}$ : «como heridas mal cerradas, sus grietas rojizas muestran una flora agreste y virulenta, zarzas y cardos y pitas de afiladas púas $»^{20} ;$ «No, dice papá, estoy en el lugar que me corresponde, dentro de esa herida mal cerrada en la tierra, una barranca hedionda y falaz $»^{21}$. La desmitificación y la resistencia a cualquier petrificación del heroísmo, encarnadas en las palabras amargas de Víctor Bartra, atañen a la propia sangre: «La sangre derramada por la patria no se infecta jamás, es inmune a cualquier microbio, porque ya está podrida y bien podrida ${ }^{22}$. La sangre, la marca de la familia Bartra, es por extensión también «la marca de los desafectos ${ }^{23}$ buscada por el inspector Galván. Por el contrario, las lagartijas cazadas por David y Paulino no tienen sangre, sino que sueltan «un agüilla viscosa y fría, como el sudor de la mano del poli» ${ }^{24}$. Es por ello por lo que hay rasgos de reptil en el rostro del inspector Galván: «una cara en la que, en ocasiones, el ave de rapiña y el reptil se confunden ${ }^{25} \mathrm{y}$, de nuevo, en su mano, que aplasta el cigarrillo contra la mano de Fermín, el proyeccionista salvajemente golpeado por la policía: «David se figura la mano magullada de Fermín entre las manos del poli: el rabo de una lagartija se agita en la palma encharcada de sangre ${ }^{26}$.

Podemos volver a las reflexiones de Malabou y a la capacidad de regeneración del rabo de la salamandra mediante la desaparición de la cicatriz. Las cicatrices de los vencidos, que representan de hecho heridas imposible de cicatrizar, son diferentes de las cicatrices de los vencedores. La cicatriz del inspector es «diminuta»-«Tiene el labio superior musculoso y bien dibujado, con una diminuta cicatriz vertical, un pliegue oscuro que le da un aire desdeńoso a

15. Op. cit., p. 71.

16. Ibidem.

17. Op. cit., p. 132.

18. Op. cit., p. 55.

19. Op. cit., p. 335.

20. Op. cit., p. 75.

21. Op. cit., p. 297.

22. Op. cit., p. 78.

23. Op. cit., p. 112.

24. Op. cit., p. 62.

25. Op. cit., p. 164.

26. Op. cit., p. 261. 
la boca ${ }^{27}$ - y la cicatriz del guardia joven al que David cuenta que ha visto caer el bombardero es casi vistosa, como indican el verbo «luce» y el adverbio «hermosamente»: "luce una cicatriz en forma de estrella que le frunce hermosamente la barbilla $»^{28}$. En cambio, la cicatriz de la rodilla de la chica con que se acuesta Fermín es "muy fea»: «esa jodida cicatriz de la rodilla [...] Es una cicatriz muy fea, la verdad ${ }^{29}$. La cicatriz en el cuerpo de los vencidos es la cicatriz imborrable de la historia colectiva y de la memoria, como leemos en $\mathrm{Si}$ te dicen que ca $\imath^{30}$ : «imborrables tatuajes y cicatrices en la piel de la memoria» ${ }^{31}$. La memoria tiene su piel, como un cuerpo. Y tal vez no sea casual que una de las cicatrices de Aurora Nin/ Ramona se describa en esta novela como un lagarto: «la cicatriz aferrada al hombro de Ramona como un lagarto rosado, cerca del cuello» ${ }^{32}$. Aurora/ Ramona es identificada por su cicatriz en el seno. La cicatriz como indicio inequívoco de reconocimiento se inscribe en una tradición que arranca desde Homero y su Odisea (recordemos que Ulises es reconocido por su cicatriz).

Los cuerpos de los vencidos acusan las magulladuras, las huellas de los bombardeos, delos asesinatos, de las mutilaciones, de las torturas. Los «muñones» son un elemento obsesivo en Rabos de lagartija, tanto al describir el barranco y su accidentada y agrietada geografía, como al fijar la imagen de «la pierna cercenada ${ }^{33}$ de Juan. Esta imagen está estrechamente vinculada por un lado al «rabo cercenado" ${ }^{34}$ de la lagartija y por otro a toda una serie de mutilaciones y torturas que aparecen en la novela y en otros textos como Ronda del Guinardó: las manos cortadas del doctor Rosón-Ansio; las manos negras, chamuscadas, del piloto de la RAF, Bryan O'Flynn; la mano flotante que David observa en el mar desde la playa de Mataró; la mano magullada de Fermín, en la que el inspector Galván apagó su cigarrillo; en Ronda del Guinardó, «las manos frías e insepultas del niño " ${ }^{35}$ Matías, que pierde las manos al manipular una granada utilizada como pisapapeles. Podemos recordar también la mano sin pulgar de Néstor en Un día volveré y el dedo perdido de Ringo en Caligrafía de lossueños. La mano es, como la cicatriz, un motivo tan recurrente en Marsé, sobre todo en Rabos de lagartija, que alcanza la categoría de obsesión ${ }^{36}$. Las manos son inseparables de la mutilación, las quemaduras, el fuego, e indefensas; los guantes aparecen

27. Op. cit., p. 116.

28. Op. cit., p. 124.

29. Op. cit., p. 256.

30. Hay una estrecha relación entre Si te dicen que caí y Rabos de lagartija (ver por ejemplo William Sherzer, «Rabos de lagartija y el papel de la intertextualidad», en Nuevas tardes con Marsé: Ensayos sobre la obra de Juan Marsé, eds. José Belmonte Serrano y José Manuel López Abada, Murcia, Nausicaä, 2002, p. 254-55).

31. Rabos de lagartija, p. 54.

32. Op. cit., p. 22.

33. Op. cit., p. 57.

34. Op. cit., p. 12.

35. Op. cit., p. 148.

36. Ver también Juan Antonio Masóliver Ródenas, «El perfume de la verdad», en Ronda Marsé, ed. Ana Rodríguez Fischer, Barcelona, Candaya, 2008, p. 462. 
como una inútil protección. Las manos del doctor Rosón-Ansio, cortadas en la plaza de toros de Badajoz, no necesitan ya los guantes de gamuza por los que pregunta el doctor en la conversación que imagina David. La mano del piloto del Spitfire derribado se aferra aún a los guantes en la fotografía que Rosa Bartra manda a David quemar junto a otros papeles comprometedores y que éste rescata del fuego. Estas manos, que el chico sigue mirando fascinado, le recuerdan la mano cortada emergiendo del mar justo después de la caída del bombardero B-26, que David presenció desde la playa de Mataró y de la que nadie quiso hablar: «Las grandes manos quemadas y tranquilamente posadas en la cintura, una de ellas sujetando todavía los maltrechos guantes de piel, le traen a la memoria otra mano todavía más negra, agarrotada y con las uñas calcinadas, meciéndose entre dos orlas de espuma blanca cerca de la rompiente de la playa de Mataró ${ }^{37}$.

La imaginación y la verdad, el espejismo y el testimonio, cuyas fronteras se mezclan continuamente en Rabos de lagartija como el rumor de voces que aturden pero también orientan a David, agudizando su percepción y su oído -no en balde sentencia Victor Bartra que «la verdad es una cuestión de oído» ${ }^{38}$-, se funden de manera magistral en la imagen de la mano que parece flotar fuera de tiempo, como un espejismo, pero que a la vez es real, forma parte de la historia silenciada, pide la atención y reclama su condición de testigo: «En una mar sofocada de espejismos, flotando fuera del tiempo, la marea alta ha estado a punto de depositarla en la arena como si fuera un pájaro mordisqueado por los peces, pero finalmente el suave oleaje de la resaca la lleva mar adentro. Segundo antes de que David la pierda de vista, la mano cortada emerge en el agua con la palma abierta como solicitando atención, haciéndole señas» ${ }^{39}$.

En el registro opuesto se describen las manos del inspector Galván. Aparentemente mansas, de la misma manera que el mechero Dupont del policía es un falso Dupont, sus manos no son lo que parecen ser y delatan, a través de la imaginación de David, la verdadera condición del inspector: «Vistas así, sumisas y pálidas, no parecen unas manos que hayan empuñado jamás una pistola, o que sean capaces de atizar puñetazos en los morros de alguien amarrado a una silla [...] Pero no me engaña su rebuscada mansedumbre, piensa David: son las manos de un tipo sin entrańas, un pedazo de cabrón» ${ }^{40}$.

Las cicatrices en el cuerpo, los cuerpos torturados, las manos cortadas, magulladas, quemadas, pertenecen a la vez al cuerpo y a la historia. Ambos son territorios cicatriciales, agrietados, resquebrajados, desgarrados, como el barranco. Los ruidos que se mezclan en el oído de David hasta llevarlo a la exasperación son los ruidos de una historia terrible, los ruidos que la verdad oficial impone callar, pero que la particular fusión de imaginación y verdad que desarrolla David resucita:

37. Rabos de lagartija, p. 121.

38. Op. cit., p. 281.

39. Op. cit., p. 121.

40. Op. cit., p. 11. 
Una flor venenosa crece en tus oídos, muchacho. No hay remedio conocido para estos ruidos y zumbidos, debes aprender a convivir con ellos y a domesticarlos, a manejarlos, a trampearlos. Debes engañarles y confundirles, o ellos acabarán contigo. Haz como que no oyes. Atiende a otras voces y llamadas, recoge otros vientos, otros ecos. Ahoga el silbido de la serpiente con otro ruido más soportable. Porque ya para siempre, hasta que mueras y el polvo de la nada se funda en tus oídos y te regale una eternidad de silencio, esos ruidos irán contigo y perforarán tus días y tus noches como los gusanos barrerán la tierra bajo el verde césped. Habrás de defenderte con uñas y dientes, muchacho. Recuérdalo siempre que mires mi oreja colgada en esa pared..$^{41}$

Las palabras imaginadas o soñadas del doctor Rosón-Ansio trazan el sino al que David no puede escapar: convertirse en una caja de resonancias de tantas heridas sin cicatrizar, de tantas cicatrices sangrantes, de tantas historias que la historia del régimen quiere enterrar, borrar, hacer desaparecer. Los «ruidos» que atormentan a David son, sin que él lo sepa, aunque empieza a intuirlo, los ruidos acallados de trágicas historias individuales, los ruidos sofocados de la historia colectiva. La «maldita y sensitiva dolencia ${ }^{42}$ de David hace posible, a través de la imaginación, que la verdad de estos ruidos se oiga, devolviendo los detalles de su historia igual que un amplificador. No por casualidad la oreja del antiguo consultorio de Rosón-Ansio con sus textos explicativos está colgada en su cuarto. Descubrir la verdad es, una vez más, agudizar el oído, conocer y activar sus funciones, distinguir los ruidos disonantes en la orquesta controlada por el poder. Por eso «el arte del buen rastreador consiste en encontrar algo que está fuera del lugar» ${ }^{43}$. El oído de David no sólo capta los ruidos acallados o enterrados, sino que también los ve: «las aguas insomnes y remotas que labraron el torrente vuelven a pasar lentas y silenciosas y llevan ojos muertos y manos cercenadas, brazos y piernas de celuloide y ropita de muñecas, zapatos viejos y aparatos de radio con las tripas fuera ${ }^{44}$. Los ve y los siente, como cuando desaparece, después de una de las tantas conversaciones que David se imagina, la presencia fantasmal, espectral, de su padre: «A sus pies, una doble hilera de guijarros blanquísimos se alinea caprichosamente entre la broza, parece una dentadura postiza que asomara mal encajada desde la entrańa de la tierra. De nuevo se siente observado, y vuelve la cabeza. Hay ojos que nos siguen mirando cuando ya se han ido ${ }^{45}$.

Los ruidos se ven y se sienten con los ojos de la imaginación y la piel de la memoria, que son los ojos y la piel de la verdad. Las aguas ya secas del barranco, las aguas de la historia, llevan «ojos muertos y manos cercenadas» y aparatos de radio que parecen cadáveres, "con las tripas fuera». No sólo la sensibilidad del oído está exacerbada en David, sino también su visión, «una visión supletoria» que le confiere al mismo tiempo el poder de "oír» la verdad, de rescatarla entre los ruidos que lo aturden y el poder de anunciarla, de anticiparla:

\footnotetext{
41. Op. cit., p. 102.

42. Op. cit., p. 97.

43. Op. cit., p. 300.

44. Op. cit., p. 97.

45. Op. cit., p. 300.
} 
La verdad aún no existe, pero David ya la dice. No encuentro una forma de explicar esa extraña facultad de mi hermano, la certera puntería de su malicia, esa flecha intuitiva, envenenada de presagios u vigilias que le proporcionan una visión supletoria, una especie de segunda oportunidad de la mirada para anticiparse a lo por venir, como alguna vez le ha pasado callejeando por el barrio con la belicosa pandilla de charnegos del Carmelo: antes de lanzar la piedra a la farola, ya ha visto en el suelo los añicos de cristal. ${ }^{46}$

Volvamos a las palabras citadas anteriormente: «esos ruidos», dice el fantasma o el espectro del doctor Rosón-Ansio, «irán contigo y perforarán tus días y tus noches como los gusanos barrerán la tierra bajo el verde césped». La comparación con los "gusanos» no es casual. El "gusano", elemento diseminado en toda la novela, agrupa varios focos textuales. Fundamentalmente es «el gusano invisible», "the invisible worm» del poema de William Blake "The Sick Rose», que Bryan O'Flynn recita una y otra vez a Rosa Bartra. The invisible worm es también la inscripción en el flanco del Spitfire derribado en la foto que David guarda fascinado en su habitación. Pero la metáfora del gusano aparece asimismo a la hora de describir un cigarrillo consumido: «un gusano de ceniza intacto» ${ }^{47}$. Si «el gusano invisible» del poema de Blake y su convocación en los labios de O’Flynn socavan la relación entre Rosa y Víctor Bartra, los ruidos que aturden a David corroen los cimientos de la verdad oficial ${ }^{48}$, irrumpen inesperadamente y, mediante una agudización extrema del oído, de la visión y de la imaginación -ya que es a través de la imaginación como se llega en Rabos de lagartija a la verdad, aunque tanto David como el lector son advertidos una y otra vez sobre el carácter extremadamente complejo y escurridizo de la verdad: "¿La verdad? Este callejón de maña muerte es tan estrecho que la verdad no pasa aquí ni con fórceps» ${ }^{49} \mathrm{o}$ "la puñetera verdad te enseña a dudar de todo ${ }^{50}-$, hacen resucitar la historia acallada. Los ruidos perforan y desestabilizan la anestesia impuesta a la sociedad y a la historia, el estado obligado de ceguera, mutismo y sordera, certificado por la amarga constatación de Víctor Bartra: "¿Para qué sirve hoy un anestesista? Hoy todo el mundo vive con la boca y los ojos cerrados y los oídos sordos. Mis servicios ya no hacen ninguna falta ${ }^{51}$. Los ruidos, a través de un exceso de visión y oído, desvelan la cohorte movida por las aguas «de ojos muertos y manos cercenadas, brazos y piernas de celuloide y ropita de muñecas, zapatos viejos y aparatos de radio con las tripas fuera». Para poder captar este movimiento desgarrado, la fusión visión-oído-imaginación ${ }^{52}$

46. Op. cit., p. 127.

47. Op. cit., p. 59. El «gusano de ceniza» aparece también en Juan Marsé, La muchacha de las bragas de oro, Barcelona, Planeta, 2006, p. 33.

48. Como las aventis en Sí te dicen que caí (ver por ejemplo Fernando Valls, «Teoría y práctica de la aventi en Juan Marsé», Ínsula, 755, 2009, p. 23).

49. Rabos de lagartija, p. 25.

50. Op. cit., p. 179.

51. Op. cit., p. 80-81.

52. Consultar al respecto la reflexión de Viviane Alary («Bryan O'Flynn, «el amigo secreto de la noche" "Ínsula, 759, 2010, p.30) sobre la capacidad de David de «desarrollar una facultad 
funciona como un estroboscopio; la verdad se muestra a destellos fugaces, como el destello del falso Dupont, del Dupont dorado del inspector Galván que Amanda debería encontrar, en la ficción que hila David para demostrar la crueldad del policía para con Chispa: «esa niña pasó cuando el tío ya estaba cavando el hoyo. Aunque el mechero debió quedar semienterrado en la arena removida, el último sol de la tarde fue capaz de arrancarle un destello, y ese destello lo vio Amanda desde su bicicleta " ${ }^{53}$. Las imágenes-destellos que los ruidos resucitan se convierten años después en testimonios fotografiados por David. Los desperdicios son sorprendidos por la cámara del ayudante de fotógrafo cuyo «interés se centra en la foto-reportaje, en captar la realidad de la calle con su propia Voigtländer de mancha y revelarla sin afeites, sin tener que retocar los negativos con el lápiz afilado ${ }^{54}$. Su enumeración recuerda el desfile fantasmal al mismo tiempo que real de los ojos muertos, de las manos cercenadas, de los cadáveres, de las mutilaciones. También las aguas actuales remiten a las aguas antiguas:

Las últimas lluvias torrenciales habían depositado en el lecho nuevas y finísimas lenguas de arena blanca, y asomaban entre el fango desperdicios diversos que David fotografió desde ángulos rebuscados y singulares: una bota militar riéndose con la dentadura de clavos torcidos, la cabeza pelona y abollada de una muńeca sin ojos mirando al cielo, media esfera de un reloj de pared con las horas transitadas por un caracol... ${ }^{55}$.

Lo que descubre y narra la cámara es la «identidad oculta» ${ }^{56}$ de estos desperdicios, su vínculo con la cohorte «de ojos muertos y manos cercenadas, brazos y piernas de celuloide y ropita de muñecas, zapatos viejos y aparatos de radio con las tripas fuera», su trascendencia "de la historia particular que pudiera sugerir su deterioro y su abandono" ${ }^{57}$ y su inscripción en la historia colectiva. De la misma manera, el tranvía bańado de agua y luz fantasmal con un único viajero borrado en la última foto conservada de David es tanto la imagen de unos destellos fugaces de belleza como «el testimonio más cabal y más veraz de lo que un día, hace mucho tiempo, conmovió a esta ciudad ${ }^{58}$. Cabe subrayar también la importancia del tranvía, que marca momentos fundamentales en la novela: la muerte del viajero que toca a Rosa Bartra, empujado por el inspector Galván bajo las ruedas del tranvía, que anuncia de alguna manera la muerte de David, y la aparición espectral del tranvía fotografiado.

La "sombra blanca» del único viajero que circula en el tranvía un día de huelga, cubierta por David a instancia del señor Marimón y de mala gana con el lápiz más afilado, es ella también una cicatriz en la piel de la memoria. La

psicológica de sinestesia absolutamente necesaria para luchar contra el presente mísero, el olvido y la anestesia generalizada».

53. Rabos de lagartija, p. 291.

54. Op. cit., p. 336.

55. Op. cit., p. 337.

56. Ibidem.

57. Ibidem.

58. Op. cit., p. 344. 
manipulación de la sombra está estrechamente ligada a la articulación verdad/ ficción que atraviesa la novela. La «sombra blanca», convertida en una cicatriz borrada, resucita en las fotografías que David hace antes de ser arrollado por un tranvía. Allí se hace tal vez visible, aunque no queda ningún testimonio, porque la cámara no es devuelta a la familia. Pero sabemos lo que experimenta David al tomar las últimas fotos de su vida: «Cada vez que tapa y destapa el objetivo siente que la verdad desnuda y simple, tal como ahora la quiere, penetra en su ojo como un rayo luminoso" ${ }^{59}$. La "verdad desnuda y simple» se describe así, "desnuda y simple», por primera y última vez en la novela. Esta verdad pertenece al campo semántico de la luz y proporciona antes de la muerte un reencuentro con la ficción, con sus ensońaciones y sus cicatrices imposibles, con las manos quemadas del piloto del Spitfire orgulloso de su cazadora: «- Las manos me arden - dice con un hilo de voz -. A que nunca has visto una cazadora de cuero como ésta... [...] Ningún agujero en la cazadora, por favor...." ${ }^{60}$. El último gesto de David parece ser la escucha del rumor del agua: «siente que se apaga el zumbido de los oídos y ladea la cabeza despacio, sin ningún signo de dolor, como si la reclinara sobre un agua que pasa para escuchar su rumor, o como si la recostara sobre la almohada arrebujado en su propio sueño» ${ }^{61}$. Es la misma agua que lleva "ojos muertos», "manos cercenadas», desperdicios que desvelan «una identidad oculta». Es el agua de la historia colectiva, la historia personal, la memoria, la reconstrucción sentimental, la sangre, la imposible cicatriz y la ficción. Es el agua del barranco, que concentra la geografía urbana y afectiva del libro y que representa un elemento que también, como la «verdad desnuda y simple», tiene que ver con la luz: «Fotografías del barranco, de lo poco que queda de sus arruinados flancos y de su vértigo infantil, en las que está depositado un sedimento del tiempo, una reflexión de la luz» ${ }^{62}$.

La ciudad es otro gran territorio cicatricial en la obra de Marsé. En Rabos de lagartija el barranco aparece desde el principio del libro como una geografía resquebrajada, desgarrada, rota: «pedruscos atrapados por raíces de higuera y muñones resecos de encina ${ }^{63}$. Igual que un cuerpo mutilado, el barranco tiene sus «muñones», que aparecen una y otra vez a la hora de construir el paisaje de la memoria sentimental, que es también el paisaje de la historia. Así, encontramos «muñones resecos de encina» ${ }^{64} \mathrm{y}$ "muñones de rosales muertos, raíces de un olivo tronchado y retońos enfermizos de geranios y adelfas junto a fragmentos del muro que encerró el antiguo jardín» ${ }^{65}$. Los «muñones» del barranco recuerdan los muñones del doctor Rosón-Ansio y también los muñones de Matías en Ronda del Guinardó.

59. Op. cit., p. 342.

60. Op. cit., p. 343.

61. Op. cit., p. 344 .

62. Op. cit., p. 337.

63. Op. cit., p. 17.

64. Ibidem.

65. Op. cit., p. 59. 
Es muy importante en este sentido destacar en Rabos de lagartija la convocación continua del campo semántico de la cicatriz, fundamentalmente a través de dos ámbitos: el de la herida o la mutilación mediante el corte («muñones», «cercenado», «tajo», «rajar», «mutilado») y el del fuego, de la quemadura (manos «quemadas», «chamuscadas», «abrasadas» o "renegridas» y dedos "chamuscados»). El adjetivo "cercenado" aparece en la novela con una recurrencia sintomática: «el rabo cercenado» ${ }^{66}$, la "pierna cercenada» ${ }^{67}$, «manos cercenadas" ${ }^{68}$. Al corte en el cuerpo, al «tajo en la nalga» ${ }^{69}$ de Víctor Bartra le corresponde la equivalencia entre el barranco y el tajo: el barranco es «un tajo muy profundo de tierra rojiza y paredes escarpadas y porosas que se desmoronan dócilmente nada más acercarte a ellas» ${ }^{70}$. Al mismo ámbito pertenecen el adjetivo «mutilado»-«el rabo mutilado» ${ }^{71}$ - y el verbo «rajar»: el «trasero rajado»" de Víctor Bartra, a quien «un cristal afilado [...] le rajó la nalga como si fuera una sandía $»^{73}$. Igual que los cuerpos y el paisaje, los objetos también están rajados, resquebrajados, desgarrados: tanto en la ficción que David inventa para su abuela como en la realidad el cuero del sillín de la bicicleta de la imaginaria Amanda está «rajado» ${ }^{74}$, marcado por el «desgarro» ${ }^{75}$. El campo semántico del fuego, de la quemadura, se construye mediante la «mano magullada» ${ }^{76}$ por el cigarrillo del inspector Galván de Fermín y «las manos chamuscadas», «renegridas» ${ }^{77}$, «quemadas» ${ }^{78}$, de «dedos chamuscados $»^{79}$ de Bryan O'Flynn, que «lucen la piel negruzca y humean un poco» ${ }^{80}$ y que traen a la memoria de David «otra mano todavía más negra, agarrotada y con las uńas calcinadas» ${ }^{81}$. Es «la mano cortada $»^{82}$, «mutilada y chamuscada» ${ }^{83}$, «achicharrada ${ }^{84}$, que flota en medio del mar como un testimonio terrible que reclama atención, pide su historia, y provoca el trayecto desde la ficción a la memoria y a la verdad.

El propio nombre del perro de David, Chispa, pertenece al campo semántico del fuego; recordemos en este sentido que el nombre del perro imaginario del niño

66. Op. cit., p. 12, 77.

67. Op. cit., p. 54, 57.

68. Op. cit., p. 97.

69. Op. cit., p. 71.

70. Op. cit., p. 18.

71. Op. cit., p. 299.

72. Op. cit., p. 277.

73. Op. cit., p. 16.

74. Op. cit., p. 104.

75. Op. cit., p. 107.

76. Op. cit., p. 261.

77. Op. cit., p. 69.

78. Op. cit., p. 121.

79. Op. cit., p. 281.

80. Op. cit., p. 110.

81. Op. cit., p. 121.

82. Ibidem.

83. Op. cit., p. 122.

84. Op. cit., p. 125. 
también llamado David (cuya abuela se llama asimismo Tecla) en La muchacha de las bragas de oro es Centella. Si estos nombres tienen connotaciones positivas, al polo opuesto se sitúan adjetivos como los ya mencionados: «chamuscados», «achicharrada» o "calcinadas». A las «uñas calcinadas les corresponde un paisaje igualmente devastado, de «ramas y troncos pelados, calcinados por el sol» ${ }^{85}$. La simetría en la utilización del mismo vocabulario, del mismo campo semántico de la cicatriz, para referirse a los cuerpos y a la geografía física y sentimental revela que esta última es, como el cuerpo y como la historia, un territorio cicatricial.

Como los cuerpos y la historia (y también como los objetos, el sillín de la bicicleta o las redes de pescar evocadas por la abuela Tecla), también el callejón y el barranco, los dos elementos fundamentales que componen "la ciudad cautiva» ${ }^{86}$ en Rabos de lagartija, están resquebrajados, agrietados, rajados. La herida, la mutilación, la cicatriz, están emparentadas con la "grieta» ${ }^{87}$ omnipresente del barranco, la grieta en la que se agazapa David ${ }^{88}$, la grieta por donde asoma la lagartija, la grieta que es de hecho una "herida mal cerrada»: "Como heridas mal cerradas, sus grietas rojizas muestran una flora agreste y virulenta, zarzas y cardos y pitas de afiladas púas»" ${ }^{89}$ La "flora agreste y virulenta» y las "afiladas púas» de las pitas conforman una geografía áspera, inhóspita, salvaje, que sin embargo se reconstruye con ternura y nostalgia en la memoria. Se trata de una geografía siempre a punto de desmoronarse: «un tajo no muy profundo de tierra rojiza y paredes escarpadas y porosas que se desmoronan dócilmente nada más acercarte a ellas» ${ }^{90}$. Es una geografía agrietada, que acumula desperdicios, heridas, mutilaciones y cicatrices en los objetos, una geografía cicatricial que recuerda las antiguas aguas, las aguas de los ruidos que atormentan y agudizan el oído y la visión de David:

\footnotetext{
De aquella torrentera que ańora David, de aquel antiguo descalabro de la tierra, hoy sólo resta al otro lado una pared escarpada y con grietas, que se desmorona día tras día, y el casi invisible estiaje del lecho, que cobija, entre desperdicios diversos, una muñeca de celuloide decapitada y vidrios rotos centelleando al sol de mediodía. ${ }^{91}$
}

Los «vidrios rotos centelleando al sol de mediodía» recuerdan el verso «A heap of broken images where the sun beats» («un montón de imágenes rotas, en las que da el sol» ${ }^{92}$ ) de La tierra baldia de Eliot. De hecho, el paisaje del barranco y el callejón componen una tierra baldía, marcada por la sequedad, por «pedruscos

85. Op. cit., p. 77.

86. Op. cit., p. 148.

87. Op. cit., p. 67.

88. Cfr. op. cit., p. 202.

89. Op. cit., p. 75.

90. Op. cit., p. 18.

91. Op. cit., p. 75.

92. He escogido ofrecer entre paréntesis la traducción para resaltar aún más el vínculo entre La tierra baldia y Rabos de lagartija. 
atrapados por raíces de higuera y muñones resecos de encina» ${ }^{93}$. El campo semántico de la sequedad se convoca de manera continua, tanto al referirse al rabo «reseco» ${ }^{94}$ de lagartija - según indica el propio título, el rabo es el foco de irradiación fundamental en la novela, que concentra todos los ámbitos ligados a la mutilación y a la cicatriz - como al fijar la geografía urbana y sentimental: "las raíces secas y retorcidas como culebras»" ${ }^{95}$ " el cauce pedregoso que poco a poco se va elevando y ensanchando hasta desaparecer confundido con las riberas cubiertas de helechos resecos y matojos»" "las raíces al descubierto, resecas y enrevesadas, de una higuera muerta ${ }^{97}$; $"$ el cauce seco desde cuánto tiempo» ${ }^{98}$. Además del verso mencionado antes, hay varios indicios que emparentan de algún modo el barranco de Rabos de lagartija y La tierra baldia, indicios agrupados en torno a los campos semánticos estrechamente vinculados entre sí de la sequedad, la cicatriz, la muerte. Recordemos la atmósfera de «El entierro de los muertos»: las «turbias raíces», los «tubérculos secos», «el árbol muerto», "la piedra seca», la «roca roja» y la interrogación "What are the roots that clutch, what branches grow/ Out of this stony rubbish? " “¿Cuáles son las raíces que se aferran, qué ramas crecen / de esa pétrea basura?»). Recordemos también los «withered stumps of time» («marchitados muñones de tiempo») de «Una partida de ajedrez», extrañamente parecidos a los «muñones» que atraviesan la novela. La propia aparición espectral de estos marchitados muñones de tiempo» -Were told upon the walls; starring forms/ Leaned out, leaning, hushing the room enclosed» («se contaban en las paredes: formas, mirando fijamente,/ se asomaban, inclinándose, acallando el cuarto encerrado») - es susceptible de vincularse al desfile fantasmal de los ruidos que la visión y el oído agudizados de David convocan en su cuarto. La "grieta» es otro elemento compartido por el texto eliotiano y la novela de Marsé. Así, en «Lo que dijo el trueno» encontramos "doors of mudcracked houses» ("puertas de casas de barro agrietado») y "the city over the mountains/ Cracks and reforms and bursts» («esa ciudad sobre las montañas/ que se agrieta y se reforma y estalla»). La tierra baldía de Rabos de lagartija es "una tierra calcinada $"$ " , "de ramas y troncos pelados, calcinados por el sol» ${ }^{100}$. La recurrencia de la calcinación del barranco se vincula estrechamente a las quemaduras, a las cicatrices en el cuerpo.

La sequedad desvela, como un palimpsesto, las antiguas aguas del torrente, las aguas que la imaginación de David arrastra de nuevo, resucitándolas. David, que tiene a la vez el poder de «una visión supletoria, una especie de segunda oportunidad de la mirada para anticiparse a lo por venir» ${ }^{101}$ y la capacidad de

93. Rabos de lagartija, p. 17.

94. Op. cit., p. 51.

95. Op. cit., p. 74.

96. Op. cit., p. 76.

97. Op. cit., p. 109.

98. Op. cit., p. 177.

99. Op. cit., p. 59.

100. Op. cit., p. 77.

101. Op. cit., p. 127. 
auscultar y ver ruidos remotos, de inventarse una verdad histórica, conquista a través de la imaginación y el sueño «esa memoria punzante y vicaria» que «contiene las aguas fangosas y violentas de otro tiempo, las aguas que socavaron el lecho del barranco» ${ }^{102}$. Si la sequedad es la huella visible, las aguas torrenciales son descifradas únicamente por David ${ }^{103}$ en palimpsesto o en filigrana detrás del "hilo de agua que parece muerta» y de los desperdicios que desvelan a su visión y a su oído su «identidad oculta», su condición de restos y testimonios de tumultuosos naufragios de la historia:

Cualquiera que se acerque a la casa remontando la suave loma desde la Avenida puede ver, en el fondo del barranco, el hilo de agua que parece muerta, la arcilla cuarteada, los desperdicios, alguna lagartija sin rabo y las raíces secas y retorcidas como culebras; pero sólo David ve las aguas turbulentas que habían atronado y descarnado los flancos del tajo, sólo él conserva aquella resonancia espumosa que inunda sus oídos enfermos y le mantiene de pie y aterido sobre el abismo, sońando historias de huracanes y borrascas, nieblas espesas y tempestades y naufragios. ${ }^{104}$

La grieta, cicatriz en el barranco y en la piel de una geografía sentimental, es la narración (recordemos las palabras de Cixous citadas al inicio del artículo, sobre la cicatriz en tanto que narración) que aúna aventura y derrota. Es la narración que da cuenta del contraste entre la sequedad actual, entre la "pared escarpada y con grietas, que se desmorona día tras día» y «aquella torrentera que añora David» ${ }^{105}$ con los ojos y los oídos de «una memoria punzante y vicaria», una memoria heredada y estimulada por la imaginación ${ }^{106}$, el sueño y el deseo de aventura cobijado en las novelas juveniles que está leyendo y que lo hacen un perspicaz observador. Desde esta perspectiva, la conexión entre la novela de Bill Barnes y la visión de la caída del bombardero B-26 y de la mano quemada en el mar es una conexión instantánea, inmediata, del orden del relámpago, del destello o del rayo, los sustantivos que designan en la novela las súbitas certezas: "Y entonces, como a la luz de un relámpago, David ve la boca del revólver acercarse a la oreja del perro y vomitar la bala que atraviesa su cabeza» (185); "Aunque el mechero debió quedar semienterrado en la arena removida, el último sol de la tarde fue capaz de arrancarle un destello, y ese destello lo vio Amanda desde su bicicleta» ${ }^{107}$; «la verdad desnuda y simple, tal como ahora la quiere, penetra en su ojo como un rayo luminoso» ${ }^{108}$.

102. Op. cit., p. 73-74.

103. Como subraya también María Esperanza Domínguez Castro «Juan Marsé: esencialismo simbólico", Dicenda. Cuadernos de Filología Hispánica, 25, 2007, p. 70. En el mismo artículo Domínguez Castro destaca igualmente la importancia del agua y el fuego (centrales en Rabos de lagartija) en la obra de Marsé (cfr. ibidem).

104. Rabos de lagartija, p. 74.

105. Op. cit., p. 75.

106. Inseparables siempre para Marsé, como atestiguan sus palabras: «Para mí el novelista es memoria, si no no sé qué es. Memoria, por supuesto, siempre a través de la imaginación» (en Gracia Jordi y Maurel Marcos, «Conversación con Juan Marsé», Cuadernos Hispanoamericanos, 628, 2002, p. 54).

107. Rabos de lagartija, p. 291.

108. Op. cit., p. 342. 
El torrente, como la historia y los cuerpos, ha sido silenciado, y su herida, su grieta, ha sido transformada en una cicatriz. Una cicatriz que puede volverse invisible: «el cauce pedregoso que poco a poco se va elevando y ensanchando hasta desaparecer confundido con las riberas cubiertas de helechos resecos y matojos» ${ }^{109}$, hasta convertirse en una cicatriz borrada. De las antiguas aguas torrenciales ha quedado como único residuo "el casi invisible estiaje del lecho» ${ }^{110}$. Pero a través de la imaginación y la memoria heredada, el estiaje vuelve a su condición inicial y arrastra los ruidos que oye David y en los que se mezcla la atracción por las novelas juveniles de misterio y aventuras y la intuición de que hay algo de la historia que no se ha contado, que permanece oculto, borrado, silenciado, como una cicatriz «casi invisible» pero real, narrable, inscrita como un tajo y una grieta en los cuerpos, en la historia y en el barranco:

\footnotetext{
Algunas noches un viento que viene del lado del barranco bate furiosamente puertas y postigos que ya nunca se abren en casa del otorrino, despierta chirridos de goznes herrumbrosos y de maderas que han muerto, y trae rumores de árboles y frondas que fulminó el rayo o arrasó la expansión de la ciudad hace años; se oyen remolinos de hojarasca, sirenas de barco en la niebla y silbos en todas las esquinas heladas del mundo. ${ }^{11}$
}

La cicatriz está inscrita también en el callejón, el otro elemento que individualiza la geografía urbana en Rabos de lagartija. Así, la tierra que forma el suelo del callejón es «roturada», marcada, llena de desperdicios, de restos, de residuos:

Un callejón de tierra apelmazada y negruzca, roturada por los juegos de navaja de los niños, apenas transitada y con orines y regueros de agua sucia y espuma de jabón, según la hora del día, así es nuestra calle, la calle que David Bartra nunca reconocerá como suya. Callejón del Viento, lo llaman a eso. ${ }^{112}$

Que el callejón es igualmente un territorio cicatricial lo atestigua asimismo su comparación con un brazo separado del cuerpo, recordando así su íntima relación con un cuerpo mutilado: «El callejón es como un brazo encogido y sarnoso desgajado del barrio en su extremo más oriental y más despoblado [... ]» ${ }^{113}$. Son sintomáticas en este sentido la alusión de Rosa Bartra al marido de la hija de Rosón-Ansio, que "perdió el brazo en un accidente»" ${ }^{114}$, y la larga serie ya analizada de manos mutiladas, cortadas o quemadas de Rabos de lagartija, que recuerdan las manos perdidas de Matías en Ronda del Guinardó.

La cicatriz en la piel de la ciudad y la existencia de una segunda piel cubierta por la primera (el ya comentado «cauce pedregoso que poco a poco se va elevando y ensanchando hasta desaparecer confundido con las riberas

\footnotetext{
109. Op. cit., p. 76.

110. Op. cit., p. 75.

111. Op. cit., p. 96.

112. Op. cit., p. 43.

113. Op. cit., p. 218-219.

114. Op. cit., p. 46.
} 
cubiertas de helechos resecos y matojos») son inseparables de la presencia recurrente de lagartijas, culebras, serpientes ${ }^{115}$. Hay una continua circulación de signos que indican la condición reptil y la capacidad de borrar las huellas de la cicatriz a través de la regeneración que oculta, «desescribe» la mutilación pero evidentemente no la anula (recordemos las reflexiones de Malabou citadas al principio de este artículo) o de la condición de la serpiente de procurarse una segunda piel. De ahí la profusión de las referencias a los reptiles y a su ausencia de sangre, ya analizada en el presente trabajo. Encontramos así «raíces secas y retorcidas como culebras» ${ }^{116}$, comparación retomada más adelante en la novela al describir la aparición espectral de Víctor Bartra: «Como oscuras serpientes enroscadas en el aire, las raíces de la higuera muerta coronan su cabeza surgiendo del flanco escarpado del torrente» ${ }^{117}$. Cabe destacar el vínculo entre el movimiento arrastrado de los reptiles (lagartijas, culebras, serpientes) y del estiaje y el movimiento de arrastre, de disimulación, de disfraz, al que es forzada la verdad: «en estos tiempos la verdad discurre a ras del suelo, como el turbio estiaje de este torrente bajo la neblina del amanecer ${ }^{118}$.

La ciudad, un «decorado maltrecho», aparece bajo el signo de lo fantasmal, lo espectral y el espejismo, participando de esta manera de la peculiar mezcla de verdad y ficción que atraviesa Rabos de lagartija: «Por la mañana temprano, arrebujada bajo un cielo aplomado y espectral, la ciudad que se extiende allá abajo parece un espejismo chafado reverberando su descalabro de grises frente al mar, un decorado maltrecho ${ }^{119}$. Un paisaje similar aparece también en Últimas tardes con Teresa y Caligrafía de los sueños y, teniendo en cuenta la gran importancia de Balzac para Marsé, presenta algunos ecos del final de Le Père Goriot, cuando Rastignac mira con avidez París desde el cementerio de Père-Lachaise. La geografía que rodea el barranco es, una vez más, dominada por la precariedad, por la fragilidad, por un desmoronamiento inminente: «los precarios alambres del tendedero junto al tajo»" ${ }^{120}$. Todo (los cuerpos, los objetos, la historia, el espacio) se resquebraja, se agrieta, se desgarra, da cuenta de la herida y narra la cicatriz, la representación de la historia reciente, la «herida mal cerrada» que es una imposible cicatriz.

115. Laureano Bonet señala: «Son en verdad los reptiles -con su ondulación escamosa- la especie viva que más abunda en la novelística marseana» («Robbe-Grillet y el "primer” Juan Marsé: metáforas heladas frente a metáforas vivas», Insula, 755, 2009, p. 16) y Claire Vialet Martínez habla al respecto de "l'omniprésence de la figure du serpent" (L'imaginaire de l'espace dans l'ouvre de Juan Marsé. Tesis doctoral inédita, 2005, consultada en Aix-en-Provence, Université Aix-Marseille I, p. 201).

116. Rabos de lagartija, p. 74.

117. Op. cit., p. 133. Resuena en esta frase una alusión a la cabellera llena de serpientes de la Medusa, cabellera que es producto de una metamorfosis, del castigo de Minerva, como cuenta el libro IV de Metamorfosis de Ovidio (eds. y trads. Consuelo Álvarez y Rosa Ma Iglesias, Madrid, Cátedra, 2004, p. 348).

118. Ibidem.

119. Op. cit., p. 186.

120. Ibidem. 
En conclusión, podemos afirmar que un análisis detenido del vínculo entre la cicatriz y el cuerpo, la historia y la ciudad en Rabos de lagartija y un estudio de la diseminación del campo semántico de la cicatriz en la construcción de las tres articulaciones interrelacionadas permite comprobar la hipótesis de partida del artículo: el cuerpo, la historia y la geografía física y sentimental funcionan en Rabos de lagartija como territorios cicatriciales.

\section{Bibliografía citada}

Alary Viviane, "Bryan O’Flynn, "el amigo secreto de la noche"» Ínsula, 759, 2010, p. 27-32.

Balzac Honoré de, La Comédie humaine. Scènes de la vie privée. Le Père Goriot. Le Colonel Chabert, Paris, Garnier, 2008.

Bénévent González Silvina, «Si te dicen que caí de Juan Marsé: images du mythe de l'Arachné», Amaltea. Revista de mitocrítica, 2, 2010, p. 9-22.

Bonet Laureano, «Robbe-Grillet y el "primer” Juan Marsé: metáforas heladas frente a metáforas vivas", Ínsula, 755, 2009, p. 14-18.

Calle-Gruber Mireille, Cixous Hélène, Hélène Cixous, photos de racines, Paris, Des femmes, 1994.

Cixous Hélène, Manhattan. Lettres de la préhistoire, Paris, Galilée, 2002.

- Hyperrêve, Paris, Galilée, 2006.

- Le Rire de la Méduse (1975), Paris, Galilée, 2010.

Domínguez Castro María Esperanza, «Juan Marsé: esencialismo simbólico», Dicenda. Cuadernos de Filologia Hispánica, 25, 2007, p. 57-81.

Eliot Thomas Stearns. The Complete Poems and Plays. London, Faber and Faber, 1970.

- Poesias reunidas. 1909-1962, trad. de José María Valverde, Madrid, Alianza Editorial, 2002.

Gracia Jordi, Maurel Marcos, "Conversación con Juan Marsé», Cuadernos Hispanoamericanos, 628, 2002, 45-57.

Hegel Georg Wilhelm Friedrich, Fenomenología del espiritu, trad. de Wenceslao Roces, México, Fondo de Cultura Económica, 1966.

Homero, Odisea, ed. de José Luis Calvo, Madrid, Cátedra, 2006.

Malabou Catherine, L'Avenir de Hegel. Plasticité, temporalité, dialectique, Paris, Vrin, 1996.

- Changer de différence. Le féminin et la question philosophique, Paris, Galilée, 2009.

Marsé Juan, Si te dicen que caí $(1973,1989)$, Barcelona, Seix Barral, 1993.

- Un día volveré (1982), Barcelona, Seix Barral, 1989.

- Ronda del Guinardó (1984), ed. de Fernando Valls. Barcelona, Crítica, 1991.

- Rabos de lagartija, Barcelona, Debolsillo, 2000.

- El amante bilingüe (1990), Barcelona, Planeta, 2001.

- Últimas tardes con Teresa (1966), Barcelona, Random House Mondadori, 2003.

- Canciones de amor en Lolita’s Club, Barcelona, Areté, 2005.

- La muchacha de las bragas de oro (1978), Barcelona, Planeta, 2006.

- Caligrafia de los sueños, Barcelona, Lumen, 2011.

Masóliver Ródenas Juan Antonio, «El perfume de la verdad», en Ronda Marsé, ed. Ana Rodríguez Fischer, Barcelona, Candaya, 2008, p. 457-463. 
Ovidio, Metamorfosis, eds. y trads. Consuelo Álvarez y Rosa Ma Iglesias, Madrid, Cátedra, 2004.

Sherzer William, "Rabos de lagartija y el papel de la intertextualidad», en Nuevas tardes con Marsé: Ensayos sobre la obra de Juan Marsé, eds. José Belmonte Serrano y José Manuel López Abada, Murcia, Nausicaä, 2002, p. 253-270.

Tolstoi León, Guerra y paz, trad. de Irene y Laura Andresco, Madrid, Alianza Editorial, 2009.

Vázquez Montalbán Manuel, «La memoria de Juan Marsé», en Nuevas tardes con Marsé: Ensayos sobre la obra de Juan Marsé, eds. José Belmonte Serrano y José Manuel López Abada, Murcia, Nausicaa, 2002, p. 271-280.

Valls Fernando, "Teoría y práctica de la aventi en Juan Marsé», Ínsula, 755, 2009, p. 23-27.

Vialet Martínez Claire, L'imaginaire de l'espace dans l'auvre de Juan Marsé. Tesis doctoral inédita, 2005. Consultada en Aix-en-Provence, Université Aix-Marseille I. 